Przegląd Badań Edukacyjnych Educational Studies Review

ISSN 1895-4308

nr 30 (1/2020), s. 147-159

METAANALIZY

BADAŃ

EDUKACYJNYCH

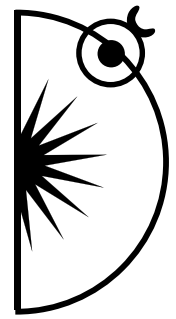

Mirosława Nowak-Dziemianowicz

ORCID: http://orcid.org/0000-0003-1148-1340

WSB University in Dabrowa Gornicza, Poland; e-mail: mirka.dziemianowicz@poczta.fm

\title{
Critical Narrative Research in Education: Theoretical Premises and Examples of Inquiry
}

http://dx.doi.org/10.12775/PBE.2020.008

\begin{abstract}
:
The article is a presentation of the author's approach in qualitative social research. Critical narrative research is characterized in the context of the linguistic turn. The author presents a model of critical narrative research, which includes the stages of critique, narrative, understanding and change, all described in detail. The article also discusses an example of critical, engaged narrative research on the struggle for recognition in narratives, based on the narrative and identity of the individual and the narrative and identity of the community as introduced by MacIntyre.
\end{abstract}

Keywords: narrative turn, critique, understanding, identity, change, struggle for recognition.

\section{Introduction}

The aim of this article is to present a (critical) narrative research orientation. This approach concentrates on seeking new perspectives in educational research as it understands the subjective practice (narrative identity) in a specific way, and it situates this practice in a "narrative reality." I will argue that a critique, which exposes or unveils meanings as well as overt and hidden power practices present in every discourse (Laclau), and which is inherent to narrative research, or even initiates such research, makes critical narrative research possible. I will outline my own notion of this kind of inquiry with its subsequent stages. I will 
also illustrate it with examples from my own critical narrative study. This article is therefore meant to justify the claim that critical narrative research in the field of education is both possible and important. Narrative research developed as a result of the linguistic turn in human and social science, thus the article begins with a brief overview of this turn. I conceptualize narrativity and the narrative as a linguistic way of being in the world, a way of constructing the social world, and a kind of modern identity. Critical narrative research gives an opportunity to understand and transform those aspects of our lives and our perceptions of ourselves and of the world, which are the sources of oppression, suffering, conflicts or failures. I see criticality, that is, ability to unveil overt and hidden patterns of power, domination and manipulation, as a condition for the change-oriented narrative research. It gives voice to those who often "cannot speak" and makes hearing this voice possible. Critical narratives (often narratives of suffering) are a condition for understanding and change, where change, as a result of such research, can be seen both as a type of the researcher's engagement and as the narrator's self-awareness in regard to his or her situation and its causes. This self-awareness is the beginning of change on individual and social levels, where the former refers to one's life, biographic plan and private action strategies, while the latter concerns attempts at action for others' empowerment, emancipation or liberation.

\section{Narrative turn and educational research}

The social sciences have been undergoing a permanent change as evidenced (in the very language in a number of research fields) by numerous "turns": the linguistic turn (Rasiński, 2009; Dziemianowicz, 2016), the action turn (Gołębniak \& Červinková, 2010), the visual turn (Sztompka, 2005), and the performative turn (Domańska, 2007). Also the narrative turn belongs to those epistemological changes as it transforms and broadens the meaning and function of the narrative and of the narrative-based or narrative-related inquiry. New perspectives in social research, and thus the subsequent turns, were preceded and enabled by the linguistic turn.

The linguistic turn signifies a transition from the tradition of representation (based on the sign-idea-thing triad, in which a sign, for the purpose of communication, replaces an idea or a thing) to the conviction that the meaning of a sign (word) is defined by how the sign is used. This conviction rests on the assumption that the use of language is like a game in that it draws from certain rules (Wittgenstein, 2009). The game is equivalent to a convention known to 
those who use the language and follow the rules as they cannot change the convention; they can only accept the rules. Indicating a similarity between the use of language and the logic of game, Wittgenstein notes that the rules may be used adequately or inadequately, just as a given word can be used in a right or wrong way. One can play or not play the game, one can speak or not speak, but one cannot change the rules after entering the game. The language game is "the whole, consisting of language and activities into which it is woven" (Wittgenstein, 2009, p. 8), which means that speaking belongs to a way of being.

As a conceptual category, narrative serves to describe a wide range of social practices and behaviours. No longer rooted in literature, its meaning exceeds the notion related to epic genres, stories or storytelling. It is present in the public sphere and used for technocratic and social-engineering purposes in marketing and politics. Narrative is also seen as a cognitive scheme beyond its media, that is, literary or historical writings. As Loba (2013) argues, the use of narrative in social research methodology emphasizes a multilayered nature of how we experience the narrative as it is linked to the individual's existence in various dimensions "sensual and intellectual, esthetic and ethical, cognitive and literary" (Loba, 2013, pp. 185-186).

The narrative turn is a consequence of a new approach to language, which emphasizes meanings that narrators give to their own experiences. It also results from the assumption that our human experience actualizes through language, not outside of it. The linguistic nature of social reality, and this reality's construction based on words carrying concrete (and individually assigned) meanings, are "marginal conditions," as it were, for the narrative turn in the social sciences. As Olga Tokarczuk said in her Nobel Lecture: "The world is a fabric we weave daily on the great looms of information, discussions, films, books, gossip, little anecdotes. (...) When this story changes, so does the world. In this sense, the world is made of words." (Tokarczuk, 2019)

The question about a narrative research orientation is an ontological question, and the way it is answered indicates one's perspective on how to approach, design and conduct research in human and social sciences. This ontological question leads to an epistemological one: the question of possibilities, boundaries and ways of our knowing of this particular aspect of reality, which we call the human world. Choosing the narrative perspective, we thus always face two questions: what the social reality is, and how we can know this reality. When making an effort to enter the process of studying the human world or its part, each of us must address these two questions, keeping in mind that they are eternal disputes or intellectual traditions present in humanities. In the narra- 
tive research perspective, the answer to the ontological question rests on the assumption typical for the interpretive sociology: the world investigated by social sciences is imbued with meaning constituted in everyday-life acts of the individual. The answer to the epistemological question rests on the conviction that social-scientific interpretation is merely a continuation of the processes of understanding, which take place in everyday life. The epistemic objective of this approach is to capture acts of interpretation and constitution of meanings actualized by the participants of the social world, as well as interpretation of diverse constructs constituted through these acts. My inspirations for this kind of reflection come from works by authors associated with interpretive sociology: Max Weber, Alfred Schütze, Marek Ziółkowski, Marek Czyżewski (Czyżewski et al., 1996), philosophers: Edmund Husserl, Martin Heidegger, Jürgen Habermas, as well as psychologists: Jerzy Trzebiński, Piotr Oleś and cultural anthropologists like Katarzyna Rosner.

Education is a narrative discipline as its basic concepts, such as educating, upbringing and others, are themselves narrative categories. Education as a science requires access to a special kind of experience shared by all people: being the subject of education, both as educator and educatee. Education is a polysemic and complex term, one that is susceptible to simplifications and ideological claims. Difficulties in the study of education result from these very features. We need more than a filled-out questionnaire, diagnostic test or observation form to address questions: How do I educate? What kind of teacher, parent or adult am I? How was I educated? How did my educators (parents, teachers and other significant individuals) act upon me? Answering such questions is not possible on the basis of indicators, formalized criteria, and objective evidence. Such answers will be partial, declarative or wishful, like those we find in many studies that, while pretending to be education research, in fact study only our opinions about education. However, such answers can be provided on the basis of heard narratives. I see education research as a discipline whose specificity and research object become an opportunity and possibility to understand complex conditions of cultural and educational crises as well as to overcome them. Narrativity in education as well as narrative educational research provide such a chance.

The question of identity belongs to central contemporary issues, including those of education field, because the permanent and lifelong construction of individual's identity is among the purposes and tasks of today's education. Therefore, the narrative approach to identity is also important.

Narrative notions of self or identity of the individual demonstrate what kinds of experience underlie the effort of making one's own story of the "self." 
These notions show how, despite the changing conditions and circumstances, people attempt at sustaining their autobiographical narratives, how they handle critical situations, how they strive to maintain their own stories when their fundamental values, convictions and actions are being questioned. A number of identity scholars consider the ability to sustain the "self" narrative or story as a key condition for identity construction and continuity. The significance of narratives is closely related to the present change in philosophy and social sciences, which acknowledges a leading status of self, identity and human subject as conceptual categories. Identity narratives are narratives that concentrate on how people, by telling their biographic stories, construct their identities. Such narratives focus on "work on identity" under specific institutional, organizational, discursive and local cultural contexts. Narrative is thus a lived experience. In this approach, what is told and how it is told are both significant aspects. Narrative practices are important as it is through them that people engage their (available) resources in order to build their recognizable "self." These narratives are typically oriented at exploring a commonality of experience. Inspirations for such explorations come from philosophers such as Heidegger (2010), Ricoeur (1989) and Habermas (1998), psychologists such as Oleś and Straś-Romanowska, and sociologists such as Giddens (1991) or Kaufmann (2012; 2013).

\section{Critical narrative research}

Criticality of narrative research in education concerns the ability to uncover and unveil oppression, hegemony, manipulation and power, and to let stories of those subject to those mechanisms be heard. Theoretical inspirations for such research can be drawn from a theory of self and community narrative identity outlined by MacIntyre (1984) in his book After Virtue, where he points to the community origins of our ethnical convictions. Communities in which we live are not made of isolated and autonomous individuals. We are born into communities, socialized within them, and taught the rules of speaking about ourselves, about others and about our interpersonal relations. In our communities we take actions aimed at us surviving as community members and as the whole community whose continuity and permanence we desire and need. Mastering a language of the community and learning specific narrative ways to speak about the past and about the present norms, is the condition for belonging. Narrative practices of telling one's own story located in the past, the presence and the future, are constitutive for human existence, and they build a non-individualist (that is, rooted in the community and related to it) conception of the human person. The 
notion of non-individualist refers to the community as a source of our narrative practices. MacIntyre suggests that the community-based narrative practices are primary, formed by tradition and located in social relations. MacIntyre claims there is no other rationality than that which is rooted in community, and each specific rationality is typical for the community that produced it within its own tradition (Chmielewski, 1996, p. XXXV).

This perspective includes all kinds of intervention and engaged research aimed at making the hitherto marginalized voices heard. In the narrative research orientation, not only contents, construction and meanings of narratives are of importance, but also their location, that is, structural positioning and power of the speaking subject's "voice." Narrative engaged research highlights voices of individuals or groups, which had been silent, whether this silence was an overall marginalization or concerned some specific issue. These aspects draw a distinction between narrative orientation in human and social sciences, including education, and perspectives traditionally grounded in the positivist paradigm. Narrative research focuses on understanding, explaining, modifying, correcting or even changing the institutions, rules and values of the social world. The intention to change, or the reason for engagement, always comes from a given scholar's emancipatory claim to deal with injustice, inequality, domination or exclusion not only in a descriptive or explanatory way but also to facilitate emancipation of the subjugated, inclusion of the marginalized, and self-awareness of the "ignorant." In the critical narrative research approach, description, explanation and understanding are deployed in order to make the social world more accommodating to those suffering oppression, those subject to symbolic power of culture, and those whom some external factors force to stay silent. The significance of individual's narrative was noted by Tokarczuk: "What first-person narratives have done for literature and in general for human civilization cannot be overestimated - they have completely reworked the story of the world, so that it is no longer a place for the operations of heroes and deities upon whom we can have no influence, but rather a place for people just like us, with individual histories." (Tokarczuk, 2019)

In the context of the narrative turn in education research, it is possible to follow a sequence of cognitive, descriptive and interpretative actions. The sequence I would like to propose is: Critique - Narrative - Understanding Change. The sequence demonstrates stages each narrative researcher must follow, and it indicates functions and objectives of this kind of inquiry. Each stage can be both a component of the research process and its purpose. The critique as critical competence, or ability to unveil power dimensions hidden in practices, 
relations and social situations, enables the narrator to be noticed and heard, and it helps to identify modes of oppression and suffering articulated implicitly by the narrator. Critique thus understood is a starting point for the change-oriented narrative research. It aims at diagnosing nature, essence and scope of the problem, and allows in-depth insight to the narrator's experience regardless of the location of voice. In other words, the critical approach is essential for the narrative research to identify assumptions, mechanisms, values, ideologies and interests implicit in any mode of power and underlying the actions of individuals, groups and communities.

The narrative approach to identity is a way to analyze phenomena, actions, relations, behaviors or people. Therefore, the narrative is the next step in this methodological sequence. Narrative identity is a biographic story located in time, structured linguistically, dynamic and changeable, that is, constantly built and rebuilt, always open and incomplete. In short, narrative is a way to understand people and their relations in the world.

The next step is the understanding, which is both the way of being in the world (Heiddeger, 2010) and the objective of all human knowledge. I agree here with Gadamer's contention that to understand means to find oneself in a situation different from when one had not understood. The understanding is equally about "self" and about the Other, thus having a relational dimension. In Husserl's account, the understanding of other people is ontic, where we understand others as subjects sharing with us understanding of objects seen and experienced by ourselves (Husserl, 1989). Thus the other is understood through ourselves thanks to the shared ways of relating to the surrounding world. Experiencing the other (both as individual or as a group or community) helps me understand my own world constituted in mutual agreement with other people this is an important aspect of the narrative educational research. And what could be another purpose of educational research aimed at grasping the complex and ambiguous process of enculturation as well as constant work on identity, if not through understanding?

Narrative as a self-story, sustained despite the changing conditions, is closely linked with the understanding. Rosner (2003) notes both "the sequence of events and meanings built upon them" as defining features of the narrative, and she argues that an analogy between the narrative and the understanding lies in their specific temporality: "the meaning of earlier events is defined by results, not otherwise, and the process of understanding encompasses the whole sequence at any moment; as long as it is unfinished, it can be subject to profound reinterpretation" (Rosner, 2003, p. 7). 
The final stage of the proposed sequence is the change in the situation of an individual, a group, a community or an institution under oppression, experiencing exclusion or failure. The change concerns education, schools and teachers as well, and it means transformations in human relations towards greater satisfaction, justice, emancipation and conditions fostering development, where people are treated as equal subjects, and where an oppressive situation of suffering is replaced, a critical event turned into a creative one, and a crisis turned into a therapeutic opportunity to extend the potential for advancement. The ability to transform institutions, relations and behaviors of other people (i.e. everything that education is about, both as social practices and a scientific discipline) is possible through the indicated sequence: the critique as competence and attitude towards social world; the narrative as a way of approaching other people's experiences, actions and identities; the understanding as both a way of being in the world and the objective of study, description and interpretation. In the proposed approach, contrary to frequent charges, the narrative educational research is not "creative writing," but a social practice involved in change, and as such highly relevant to education as a scientific discipline.

\section{Struggle for recognition as an example of change-oriented critical narrative research}

Narrative research concerned with the struggle for recognition is an example of the proposed sequence of Critique-Narrative-Understanding-Change. The struggle for recognition is both a condition and a possibility to work on one's identity. It might be a way of restoring the threatened and unstable individual identity. Then it becomes a highly relevant individual category to describe the individual and his or her predicament and actions. The struggle for recognition thus becomes a biographic category. Yet it can be treated as a condition for social change and social development, as it relates to community as well.

As the notions of identity and recognition are interrelated, my own studies have been grounded in MacIntyre's (1984) concepts of the individual and community narratives. Based on these categories, I argue about the significance of identity today and of constant efforts at biographic identity constructions. I place narratives among the consolidating identity practices, that is, actions that ensure the individual's sense of continuity and persistence in the changing contemporary reality. The narratives I describe and interpret are narratives of recognition, which are always individual but accompanied by community narratives that provide contexts and meanings to recognition narratives. The 
notion of links between the individual and the community as reflected upon my MacIntyre (1984), is not merely functional for interpreting the narratives. It also provides a convincing answer to our contemporary problems (including those we face in the Polish context): how and based on what contents, meanings, rules, norms and values our identity is built and recognized. The individual and community narratives are not only about biographic self-stories, but also our ways of being in the world providing us with the existential unity. Regardless of the changing circumstances in our lives, whether we succeed or fail at realizing our plans, fulfilling our dreams and achieving our goals, our self-narrative is what distinguishes me from others and serves as the basis for self-autonomy and uniqueness. Self-narratives are the basis for our self-understanding: we are what we know about ourselves and what we tell about ourselves. The narrative of our community can be characterized in a similar way, as the meanings constitutive for our individual identities are grounded in rules, norms, role regulations and expectations shared on the level of community. Whether we accept the community narrative (and whether it is coherent or single) or not, it determines who we are and what we are like. Its meanings become our signposts and the relevant context for our choices. But these meanings can also be subject to our refusal, dissent or resistance. Regardless of our attitudes towards the contents of our community narratives, we cannot avoid relating to these narratives in some way, whether accepting, challenging or rejecting them.

I see the recognition (Honneth, 1995) as both a condition for identity construction and a major issue in the individual's personal work on self-identity - his or her need and pursuit. It is necessary for creating one's sense of autonomy while at the same time maintaining the sense of bonding with others and belonging to a community. Deficit of recognition makes people vulnerable to manipulation, deprives them of agency and ability to make choices. Such deficits can be identified through the adopted critical perspective.

I used four individual narratives and four community narratives to describe and interpret the struggle for recognition. The first one is a kind of "road narrative", where the sense of deficit is a constant biographic problem. The particular example in question is a narrative of a Polish Jewish woman who struggles with dual identity in that she cannot and does not want to accept her Jewish origins. The struggle for recognition takes place on two levels: the woman struggles with herself as she is unable to self-recognize and value her descent, and she also struggles with her social environment: friends, acquaintances and anyone whom she sees as potentially rejecting. This individual narrative is accompanied with the community narrative immersed in complexity of Polish-Jewish re- 
lations marked by positively-valued instances of coexistence, including rescue of the Jews by non-Jewish Poles during the Holocaust, but also by the lasting antisemitism as a generalized hostility towards "strangers." This critical narrative exposes oppression, and it enables the understanding of a problem necessary to resolve in order to foster change in the individual and in the community.

The second example of the struggle for recognition is based on narratives of mothers and daughters. Drawing on the notion of recognition, psychoanalytical theories as well as socio-political categories, I address the questions of suffering present in mutual relations of mothers and daughters: its individual, psychological and cultural sources, and possibilities to overcome it or minimize its effects. Therefore, I examine possibilities of change, starting from the critical approach and in-depth interpretation of the narratives. The critical perspective allows exposing individual and community instances of oppression and, based on the understanding of the nature and effects of this oppression, it opens up possibilities of change aimed at reducing the deficit of recognition.

The third example is based on marital narratives. In the contemporary world of individualism, the intimacy of the relationship has become one of the most crucial values. However, at the same time, this value is highly problematic. Interpretation of this kind of struggle for recognition reveals dangers and traps of symbolic violence to which women are often subject. It also shows what can be done to avoid it. The sequence for inquiry here is, again: criticality, the narrative listened to and interpreted, the understanding and change. On the individual level, the change means acting against symbolic violence, while on the social level it is a justification for an emancipatory social project.

The fourth and last example concerns the experience of contempt, which Honneth sees as a result of the refusal to recognize. I analyze this extreme, liminal experience on the basis of narratives provided by persons who had been subject to sexual harassment as children. I treat this inquiry as the educational researcher's commitment to give voice to those who suffer, and whose suffering is not their fault; those who cannot constructively build their own biographies and develop their self-identities. The critical perspective opens up here to the experience treated as a social taboo; the understanding enables the struggling individuals and the denying community to face the problem; and the change means liberating the victims of abuse from the trajectory of suffering.

I think the Critique-Narrative-Understanding-Change sequence can serve as a valuable research approach relevant to contemporary issues. 


\section{Conclusions}

The struggle for recognition in narratives can be a beginning or a form of social change towards a community constituting an alternative to the oppressive neoliberal social order. Such a community might replace the dominant power of the market, money, profitability and efficiency legitimized by the language of economics. The community might enable each individual and group to build the relations of recognition and achieve a life that would be satisfactory as it would be based not only on the material good but also on spiritual, existential, emotional and inter-subjective notions of human well-being. A happy life does not have to be grounded in the rules of economics. It can draw from the principles of the good life shared by the many; the life with others. Only the other's presence gives us what is most precious to us, and relevant to our identity and self-esteem: it gives us recognition. At the same time, individual self-narratives do not have to isolate us from other people. This is Tokarczuk's concern when she says: "We have determined that this type of individualized point of view, this voice from the self, is the most natural, human and honest, even if it does abstain from a broader perspective. Narrating in the first person, so conceived, is weaving an absolutely unique pattern, the only one of its kind; it is having a sense of autonomy as an individual, being aware of yourself and your fate. Yet it also means building an opposition between the self and the world, and that opposition can be alienating at times." (Tokarczuk, 2019) Making the community narrative heard enables this opposition to be understood better, and perhaps, I hope, even overcome it. Critical listening, describing and understanding of the individual and community narratives, opens the way to change by realizing it is needed, possible and achievable.

\section{References}

Bobako, M. (2012). Zaklinanie nowoczesności. Axel Honneth i moralna gramatyka filozoficznych przemilczeń [The Conjuring of Modernisty: Axel Honneth and Moral Grammar of Philosophical Concealments]. In: A. Honneth (Ed.), Walka o uznanie. Moralna gramatyka konfliktów społecznych [The Struggle for Recognition], (pp. XXVII-XLIII). Kraków: Zakład Wydawniczy Nomos.

Burzyńska, A. (2008). Idee narracyjności w humanistyce [Ideas of Narrativity in Humanities]. In: B. de Barbaro, B. Janusz, \& K. Gdowska (Eds.), Narracja. Teoria i praktyka [Narrative: Theory and Practice], (pp. 21-36). Kraków: Wydawnictwo Uniwersytetu Jagiellońskiego. 
Chmielewski, A. (1996). Wprowadzenie. Filozofia moralności Alasdaira Maclntyre'a [Introduction: Alasdair MacIntyre's Moral Philosophy]. In: A. MacIntyre (Ed.), Dziedzictwo cnoty [After Virtue], (pp. 7-58). Warszawa: Wydawnictwo Naukowe PWN.

Czyżewski, M., Piotrowski, A., \& Rokuszewska-Pawełek, A. (Eds.) (1996). Biografia a tożsamość narodowa [Biography and National Identity]. Łódź: Katedra Socjologii Kultury Uniwersytetu Łódzkiego.

Domańska, E. (2007). „Zwrot performatywny” we współczesnej humanistyce [‘The Performative Turn' in Contemporary Humanities]. Teksty Drugie, 5, 48-61.

Giddens, A. (1991). Modernity and Self-Identity. Self and Society in the Late Modern Age. Cambridge: Polity.

Gołębniak, B. D., \& Červinková, H. (Eds.) (2010). Badania w działaniu. Pedagogika i antropologia zaangażowane [Action Research: Engaged Pedagogy and Anthropology]. Wrocław: Wydawnictwo Naukowe DSW.

Habermas, J. (1998). The Inclusion of the Other: Studies in Political Theory. Cambridge, Massachusetts: MIT Press.

Heidegger, M. (2010). Being and Time. Translated by J. Stambaugh. Albany, New York: SUNY Press.

Honneth, A. (1995). The Struggle for Recognition: The Moral Grammar of Social Conflicts. Translated by J. Anderson. Cambridge: Polity Press.

Husserl, E. (1989). Ideas Pertaining to a Pure Phenomenology and to a Phenomenological Philosophy: Second Book. Translated by R. Rojcewicz, \& A. Schuwer. Dordrecht/ Boston/ London: Kluwer Academic Publishers.

Kaufmann, J.C. (2012). Niezwykła historia szczęśliwej miłości [The Curious History of Love]. Warszawa: Oficyna Naukowa.

Kaufmann, J.C. (2013). Kiedy Ja jest innym [When the Self is the Other]. Warszawa: Oficyna Naukowa.

Loba, M. (2013). Wokót narracyjnego zwrotu. Szkice krytyczne [On the Narrative Turn: Critical Essays]. Poznań: Wydawnictwo Naukowe UAM.

MacIntyre, A. (1984). After Virtue: A Study in Moral Theory, 2th ed. Notre Dame: University of Notre Dame Press.

Nowak-Dziemianowicz, M. (2016). Walka o uznanie w narracjach. Jednostka $i$ wspólnota w procesie poszukiwania tożsamości [The Struggle for Recognition in Narratives: Self and Community in Serach for Identity]. Wrocław: Wydawnictwo Naukowe DSW. 
Oleś, P., \& Puchalska-Wasyl, M. (Eds.) (2011). Dialog z samym soba [Dialogue with Oneself]. Warszawa: Wydawnictwo Naukowe PWN.

Rasiński, L. (Ed.) (2009). Język, dyskurs, społeczeństwo [Language, Discourse, Society]. Warszawa: Wydawnictwo Naukowe PWN.

Ricoeur, P. (1989). Język, tekst, interpretacja. Wybór pism [Language, Text, Interpretation: Selected Writings]. Warszawa: Państwowy Instytut Wydawniczy.

Rosner, K. (2003). Narracja, tożsamość i czas [Narrative, Identity and Time]. Kraków: Universitas.

Rubacha, K. (2008). Metodologia badań nad edukacja [Methodology of Educational Research]. Warszawa: Wydawnictwa Akademickie i Profesjonalne.

Schütze, F. (2012). Koncepcja świata społecznego w symbolicznym interakcjonizmie oraz organizacja wiedzy w nowoczesnych, złożonych społeczeństwach [The Notion of Social World in Symbolic Interactionism, and Organization of Knowledge in Modern and Complex Societies]. In: K. Kaźmierska (Ed.), Metoda biograficzna w socjologii [Biographic Method in Sociology], (pp. 489-514). Kraków: Zakład Wydawniczy Nomos.

Sztompka, P. (2005) Socjologia wizualna. Fotografia jako metoda badawcza [Visual Sociology: Photography as a Research Method]. Warszawa: Wydawnictwo Naukowe PWN.

Taylor, C. (1980). Theories of Meaning. Man and World, 13(3-4), 281-302, doi: 10.1007/ BF01252549.

Taylor, C. (1994). Sources of the Self: The Making of the Modern Identity. Cambridge, Massachusetts: Harvard University Press.

Tokarczuk, O. (2019). The Tender Narrator. Translated by J. Croft, \& A. Lloyd-Jones, Nobel Lecture in Literature, 7 December 2019, Retrieved 20 April 2020 from https://www. nobelprize.org/prizes/literature/2018/tokarczuk/104871-lecture-english/,

Wittgenstein, L. (2009). Philosophical Investigations. Translated by G. E. M. Anscombe, P. M. S. Hacker, \& J. Schulte. Malden, Massachusetts/ Oxford: Wiley-Blackwell. 